\begin{tabular}{|l|l|l|l|}
\hline Eiszeitalter u. Gegenwart & 34 & $\begin{array}{c}7-27 \\
12 \mathrm{fig} .\end{array}$ & Hannover 1984 \\
\hline
\end{tabular}

\title{
Till in Southeast Drente and the Origin of the Hondsrug Complex, The Netherlands
}

\author{
MARTIN RAPPOL
}

Classification, till, chertification, flint poor, flint rich, outcrop, borehole section, Saalian, size distribution, heavy mineral.

Netherland Southeast Drenthe

\begin{abstract}
Saalian till of the Hondsrug was studied in several exposures in SE Drente. The results from the analyses of several parameters for till composition allow the distinction of two till types: an upper flint-poor, and a lower flint-rich till. Especially the latter often shows evidence for the assimilation of considerable amounts of local preglacial sediments. The compositional variability in vertical sections seems related to the distribution of source materials in the up-glacier areas, but processes of synsedimentary deformation may have caused the formation of a more complex vertical petrographic variation. No evidence for multiple glaciation has been found.

The Hondsrug complex forms a system of NNW-SSE striking elongated ridges on the eastern side of the Drente till plateau. It differs from the surrounding till areas not only be the deviating orientation of the ridges, but also by the East-Baltic indicator-pebble assemblage of the till. Till composition, clast fabric and subglacial deformation structures point to a glacigenic origin of the Hondsrug complex, which represents a younger ice movement within Stadial III of the Saale glaciation.
\end{abstract}

\section{[Geschiebelehm in Südost-Drente und die Entstehungweise des Hondsrug-Komplexes (Niederlande)]}

Kurzfassung: Die Grundmoräne der Saale Vereisung ist in mehrere Aufschlüsse im südlichen Hondsrug untersucht worden. Die Analyse der verschiedenen Parameter der Geschiebelehmzusammensetzung ermöglichte die Unterscheidung zweier Geschiebelehmtypen: eines oberen feuersteinarmen und eines unteren feuerstein-reichen Typs. Im unteren Geschiebelehm gibt es viele Hinweise für eine erhebliche Aufarbeitung von lokalem präglazialem Material. Die vertikale Differenzierung der Zusammensetzung des Geschiebelehmprofils zeigt Anklänge an die Verteilung des Ausgangsmaterials in den eisstromaufwärts gelegenen Arealen. Synsedimentäre Deformationsvorgänge dennoch sind teilweise verantwortlich für mehr komplexen vertikale petrographische Variationen. Es gibt keine Hinweise für eine mehrfache Vereisung.

Der Hondsrug-Komplex ist aus mehrere NNW-SSO-orientierten Rücken im östlichen Teil des Drente Plateaus zusammengesetzt. Er weicht von den angrenzende Grundmoränegebieten nicht allein durch die Orientierung der Rücken ab, sondern auch durch eine ganz andere Zusammensetzung des Grobmaterials des Geschiebelehms. Die Geschiebelehmzusammensetzung, die Orientierung der Geschiebelangsächsen und Lagerungsstörungen stehen im Einklang mit einer glazigenen Entstehungsweise. Der Hondsrug-Komplex repräsentiert eine jüngere Bewegung des Inlandeises innerhalb das Stadial III des Saale-Glazials.

Address of the author: Dr. M. RAPPOL, Physical Geography and Soil Science Laboratory, University of Amsterdam, Dapperstraat 115, 1093 BS Amsterdam, The Netherlands. 


\section{Introduction}

The Hondsrug complex (TER WEE 1979) comprises a series of parallel ridges and associated depressions along the eastern flank of the Drente till plateau. The ridges strike approximately NNW-SSE and are remarkably rectilinear in their course. In the southern part of the Hondsrug complex three separate ridges are present: the Hondsrug itself consists here of two ridges, i.e. the ridge of Klazienaveen-Emmerschans and that of Erica-Emmen, while

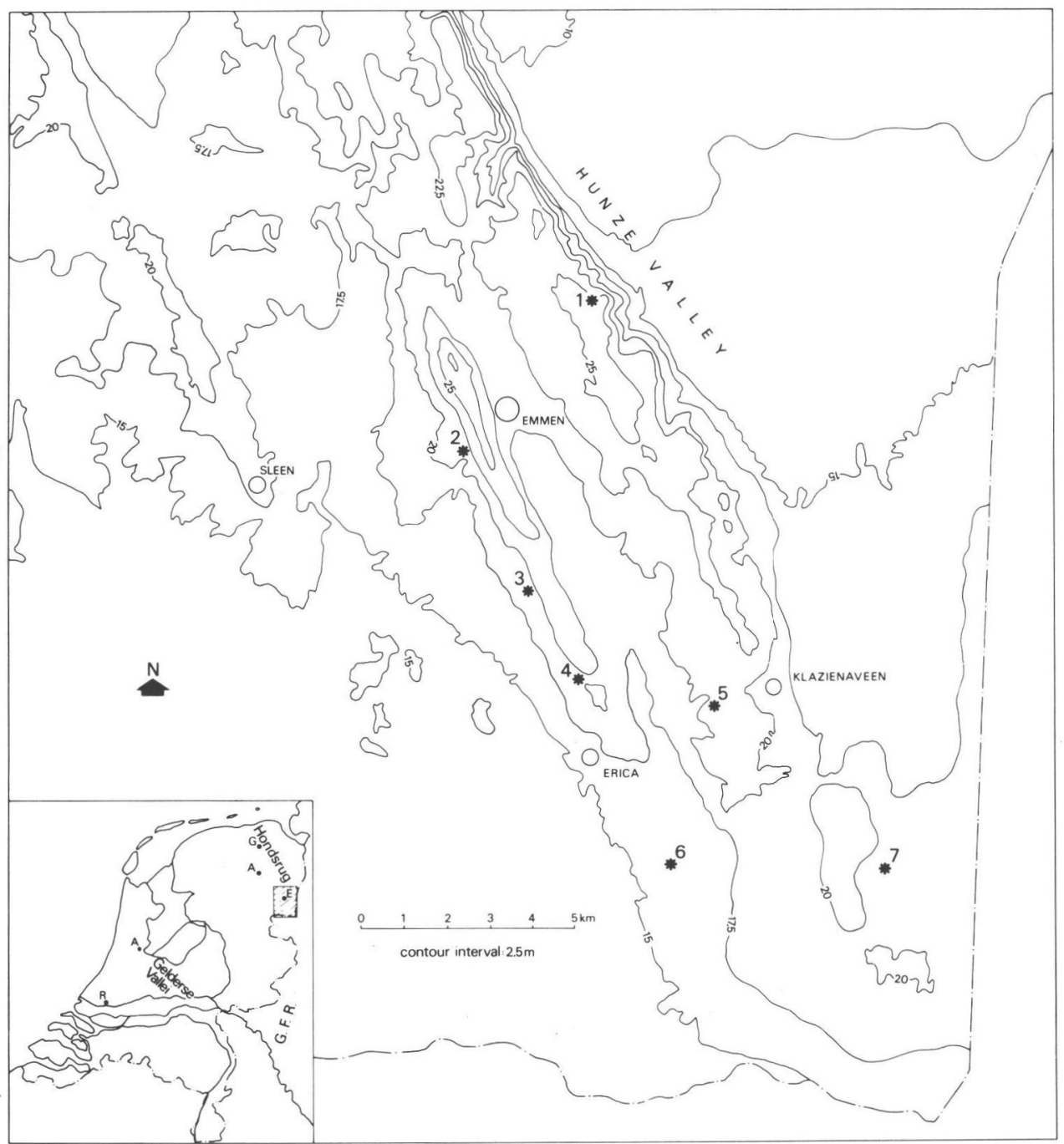

Fig. 1: Contour map of the investigated area (contour interval: $2.5 \mathrm{~m}$ ) with the location of the investigated exposures. 1. pit 'Gebr. de Boer', Emmerschans, 2. construction site of Jehovah's Witness building, Noordbarge, 3. construction site, Zuidbarge, 4. tunnel construction site, Erica, 5. canal face, Klazienaveen, 6. sand-dredging pit, Weiteveen-Noordersloot, 7. canal face in peat area of Weiteveen (Weiteveen-canal). Base maps: Topographic Map of The Netherlands 1:25.000. 
west of these the ridge of Sleen is present (Fig. 1). More to the north, in the area of the city of Groningen, five to seven ridges run parallel to each other (VAN VEEN 1925), which can be traced some distance below the Holocene cover of marine sediments in northern Groningen (ROELEVELD 1970/71).

In the east the Hondsrug complex is bordered by the present Hunze valley. The position of this valley seems related to a Saalian meltwater channel, which is filled up with glaciofluvial and younger deposits (TER WEE 1979, 1983).

In general the ridges of the Hondsrug complex have a rather low relief which is hardly perceptible in the field. Only the eastern flank of the Hondsrug is locally a conspicuous morphological feature. In the surroundings of Emmen the Hondsrug attains its greatest height: here, the ridges of Erica-Emmen and Klazienaveen-Emmerschans both are over $25 \mathrm{~m}$ + NAP (dutch datum level). This coincides with the presence of glaciotectonic deformations in the sub-soil (TER WEE 1979: profiles B-B' and D-D').

The orientation of the morphological lineation of the Hondsrug complex deviates from that of the surrounding Pleistocene areas of Ost-Friesland, Oldenburg and eastern Groningen in the east, and that part of the Drente till plateau located west of the Hondsrug complex. In these areas a NW-SE oriented ridge and drainage pattern is present (Fig. 2). This NW-SE trending lineation is generally assumed to reflect the direction of the major or last Saalian ice movement in these areas (e.g. Edelman \& MaArleveld (1958: 650, Ehlers \& StePHAN 1983).

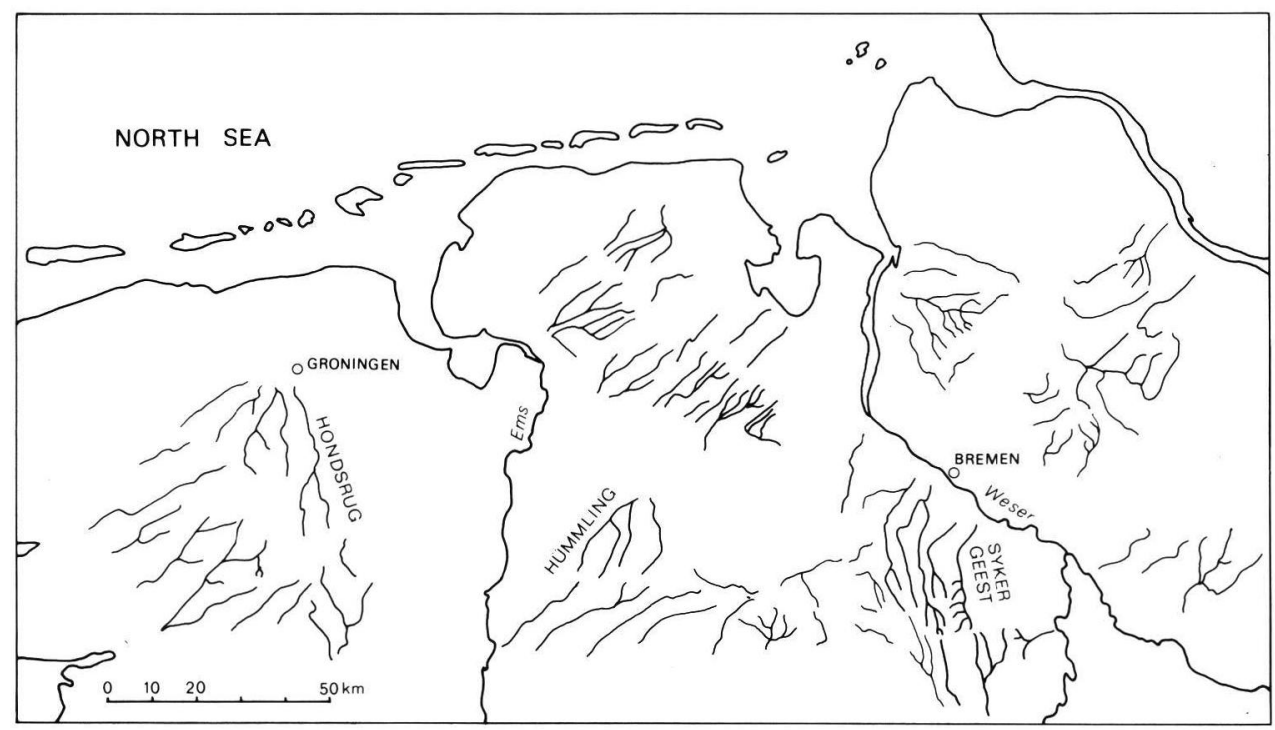

Fig. 2: Drainage pattern in the till areas of northern West Germany and The Netherlands, partly as a reflection of the last active Saalian ice movements. Note different orientations in the Syker Geest and Hondsrug areas. See also Edelman \& MaArleveld (1958, Fig. 7). Mainly after: Hydrologischer Atlas der Bundesrepublik Deutschland, Deutsche Forschungs Gemeinschaft, Bonn-Bad Godesberg.

The strikingly different orientation of the Hondsrug complex has attracted much interest, and during the long history of geologic research many different opinions about its 
origin have been expressed. Since the acceptance of the glacial theory, the Hondsrug has been considered an endmoraine (VAN CalKer 1985, MARTIN 1994), a linear feature of subglacial origin (Dubois 1902), an ice-pushed ridge, a kame (FABER 1942, Boissevain 1950) and a glacially-disturbed zone (MAARLEVELD 1956). Moreover, a tectonic origin has been popular more recently (e.g. DE GANS 1981) along with the glacial origin (ROELEVELD 1970/71; RAPPOL 1983). The lasting confusion is well illustrated by the description as given in the legend of the Geomorphological Map of The Netherlands scale 1:50.000: "ridge possibly formed by tectonic movements and probably influenced glacially” (MAARLEVELD, TEN CATE \& DE LANGE 1977).

In the present paper the term 'till' denotes a sediment formed by direct glacigenic deposition without subsequent reworking by meltwater or mass movement processes. It is especially a typical product of subglacial deposition, and is characterised by a more or less homogeneous mixture of material with particle sizes from clay to boulders. For practical reasons, the presence of non-local components is required (Dreimanis 1976: 19).

The glacial diamictons studied in SE Drente are identified as subglacial till an account of the nature of deformation structures related to the formation of these diamictons (RAPPOL 1983). Characteristics of the clast fabric and compositional variability in the diamictons are in accordance with such an interpretation (see below).

At seven sites characteristics of the till profile were studied (Fig. 1). The exposures at Emmerschans and Erica were described elsewhere in sufficient detail (RAPPOL 1983, RAPPOL \& StOltenberg 1984), and these will be mentioned here only briefly. Characteristics of the till profiles bear some important consequences for the problem of the origin of the Hondsrug complex.

\section{Methods}

Samples were preferably obtained from exposures where structural features could be studied in detail. At some sites however, samples were taken at depth with a normal soil auger.

Grain-size distributions were determined by dry sieving for the sand and gravel fractions (up to $16 \mathrm{~mm} /-4 \varphi$ ), and by pipette method for the clay and silt fractions. Moment measures (FRIEDMAN 1967) were calculated for the matrix fraction $(<2 \mathrm{~mm} /-1 \varphi)$ with grain-size fractions at $1 \varphi$ intervals and a clay fraction defined as $9-14 \varphi$.

Fine-gravel petrography was determined for the fractions $3-5$ and $2-3 \mathrm{~mm}$. Where possible, 200 to 300 particles were determined, but due to limited sample sizes of $2-3 \mathrm{~kg}$, many samples in the fraction $3-5 \mathrm{~mm}$ contain less (yet, in most cases more than 150 grains). Flint-coefficients were calculated as a measure for the relative frequencies of flint and igneous + metamorphic rock fragments. $\mathrm{F} / \mathrm{C}_{3-5}$ refers to the flint-coefficient for the fraction $3-5 \mathrm{~mm}$. In the following, flint-poor till is defined as a till increment with $\mathrm{F} / \mathrm{C}_{3-5} \leqslant 0.03$, in flint-rich till this value is higher than 0.03 .

The heavy-mineral composition and weight percentage was determined for the fraction $0.250-0.125 \mathrm{~mm}(2-3 \varphi)$. Percentage given are based on the determination of 300 transparent grains by counting in ribbons. Details of procedures and the variations of heavymineral composition in Saalian till of The Netherlands will be discussed elsewhere (RAPPOL \& Stoltenberg, in prep.). 
Elongated-clast fabric was determined by measuring orientation and dip of 40 elongated clasts $(\mathrm{a} / \mathrm{b}$ axis ratio 1.4 or higher) in till not affected by post-depositional cryoturbation.

\section{Compositional characteristics of the till profile}

\subsection{General aspects and previous results}

Saalian till in SE Drente generally overlies fine-sandy, occasionally loamy sediments of the Elsterian Peelo Formation (TER WEE 1979). Only in the area around Emmerschans older deposits are found near the surface as a result of glaciotectonic deformation (LigTERINK 1954; RUEGg \& ZANDSTRA 1977). This deformation phase pre-dates the deposition of the till; there is no relict relief related to the formation of ice-pushed ridges in front of an advancing ice margin. The sub-till sediment is moreover commonly strongly deformed by subglacial shear in a zone of one to several metres below the till base (RAppol 1983).

Within the Hondsrug complex till is found especially in the ridges. From the associated depressions the till has often been eroded, leaving only a residual stone pavement (TER WEE 1979). According to Roeleveld (1970/71: 11, see also his figures 6 and 7) there are indications that the ridges and valleys of the Hondsrug complex follow undulations of the till surface. While the lower till boundary is comparatively flat and horizontal, its upper surface shows a considerable relief. Observations by the present author at the exposures of Erica and Klazienaveen are in accordance with Roeleveld's suggestion.

Till sections in SE Drente bear evidence of one continuous ice cover only, which should be placed in the third stadial of the Saale glaciation according to the investigations of ZAGwiJN (1973). These pollenanalytic investigations indicate that the advancing ice met an open landscape or polar desert with permafrost. Also the absence of meltwater deposits below the till in the northern Netherlands suggests very cold conditions (TER WEE 1983: 406).

Results of indicator-pebble counts from the investigated area have been reported by $\mathrm{DE}$ WaARd (1949), LütTig (1958), LütTig \& MaArleveld (1961), Zandstra (1976) and SchuddeBEURS (1982). Countings following the method of Hesemann indicate a prevalence of pebbles and boulders of East-Baltic provenance throughout the Hondsrug complex (Schuddebeurs 1980/81, Schuddebeurs \& Zandstra 1983: Fig. 354). Most of these counts are based on material sampled at the till surface where the coarse material is frequently found concentrated as a result of post-depositional reworking of the superficial till material. However, samples from the lower part of the till profiles at Emmerschans and Erica also show the prevalence of East-Baltic indicators (Zandstra 1976, Schuddebeurs 1982).

However, we should note that counts following LütTiG's (1958) TGZ-method did not in all cases yield comparative results. Four out of thirteen counts reported from the southern Hondsrug area have a TGZ-value which is shifted considerably in a western direction (LütTIG \& MaARleveld 1961: 170 and figure 5). Also according to JoNKER (1905) and LigteRINK (1954: 119), West- or South-Baltic material may locally dominate in the lower part of the till profile.

The till profile at Emmerschans was first described by ZANDSTRA (1976), who could distinguish between two till types found directly on top of each other: a flint-poor upper till (Emmen-type) and a flint-rich lower till (Assen-type). Besides the striking difference in finegravel petrography, the till types were found to differ in grain-size distribution and heavymineral composition. In ZANDSTRA (1983: Fig. 364) a similar two-till occurrence is reported 
from Noordhorn (Groningen) in the extreme northern part of the Hondsrug complex. Also from the exposure at Erica both till types have been described (RAPPOL 1983).

The entire till mass in SE Drente is commonly decalcified. Only at Erica a small spot of calcareous till was found at the base of the lower till. The upper $1-1.5 \mathrm{~m}$ of the till is cryoturbated and mixed with coversand or gravelly sand, which overlies the till. Near the base of the coversand a gravel pavement or bed may be present, that was formed after the cryoturbation event. In the southeastern part of the investigated area, the coversand deposit is overlain by peat, which has partly been removed by human activities.

\subsection{Results}

Characteristics of the studied till sections are shown in Fig. 3, which also indicates the position of the analysed samples. Results of the sample analyses are schematically given in Fig. 4.
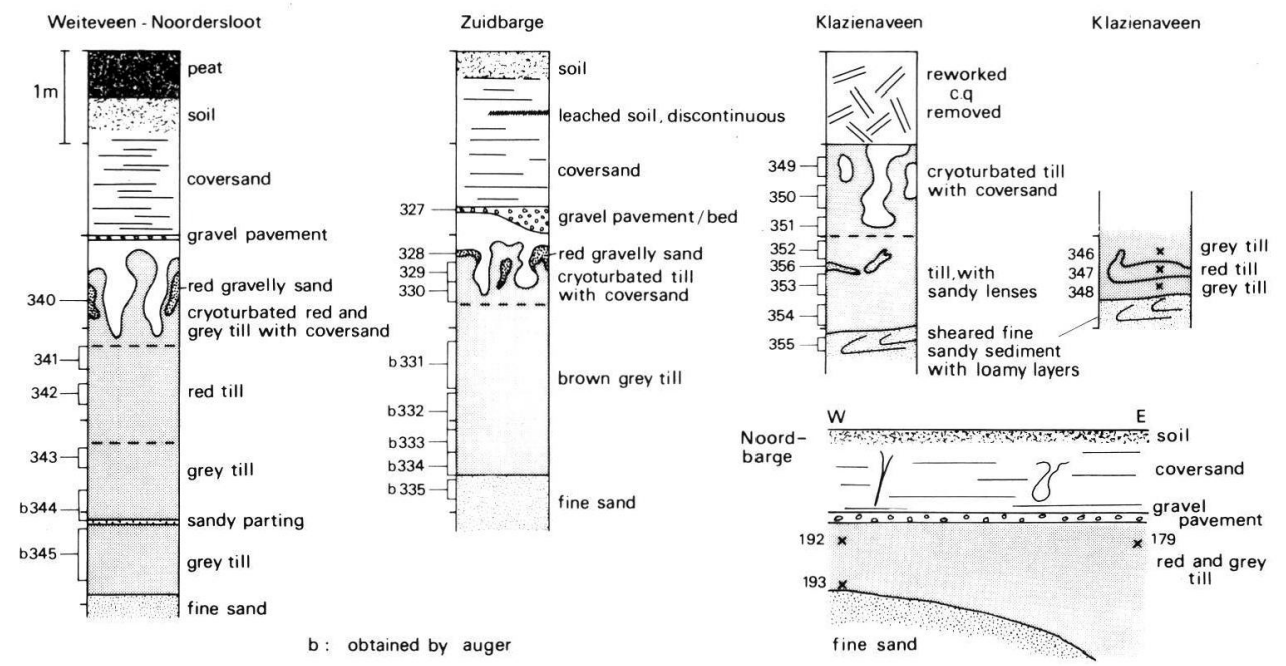

Fig. 3: Characteristics of the investigated till profiles and position of samples.

At five of the seven investigated profiles both flint-poor and flint-rich till types were identified. At Noordbarge and Weiteveen-canal only flint-rich till was found, but the latter exposure was of a poor quality and only studied superficially. Similar to the situation in the exposures of Emmerschans and Erica, flint-poor till was found in the upper part of the till profile at Zuidbarge and Weiteveen-Noordersloot. At Klazienaveen however, a lense of red flint-poor till was found near the base of the grey flint-rich till (Fig. 5, see also Fig. 3 and 4). Such a striking difference in colour is not general, however. It should be noted that at Weiteveen-Noordersloot the colour change does not coincide with the petrographical boundary, (compare Figs. 3 and 4), while at Zuidbarge no colour difference was observed in the field. In general therefore, till type can only be identified after sample analysis. At Weiteveen-Noordersloot the colour change occurs about the mean groundwater level (see also TER WEE 1983: 409).

Although the definition of flint-poor and flint-rich till is artificial and arbitrary, there is ample evidence that it concerns two different populations. Flint-coefficient values 


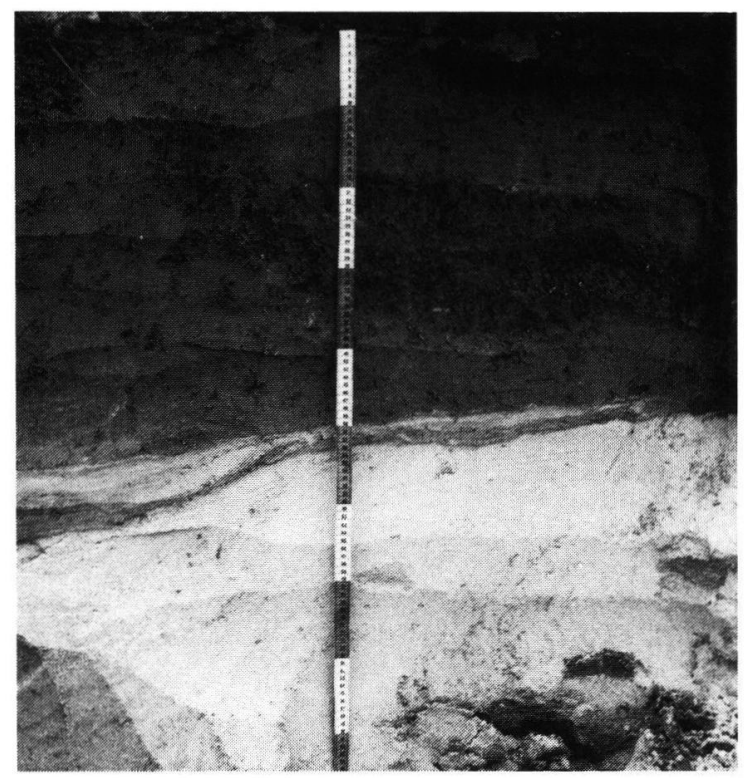

Fig. 5: Lense of red flint-poor till (darker zone, between 18 and $34 \mathrm{~cm}$ on ruler) in the basal part of the grey flint-rich till at Klazienaveen (see also Figs. 3 and 4). Below: sheared sediments of the Elsterian Peelo Formation.

between 0.02 and 0.08 are comparatively rare in the fraction $3-5 \mathrm{~mm}$ (Fig. 6), and also the values for the fraction $2-3 \mathrm{~mm}$ show a clear gap. $\mathrm{F} / \mathrm{C}_{3-5}$ modal values are $0.00-0.01$ and $0.16-0.17$, with a mean of 0.16 for the flint-rich till ( 40 samples). The mean value for the flint-rich till in the fraction $2-3 \mathrm{~mm}$ is 0.09 (25 samples).

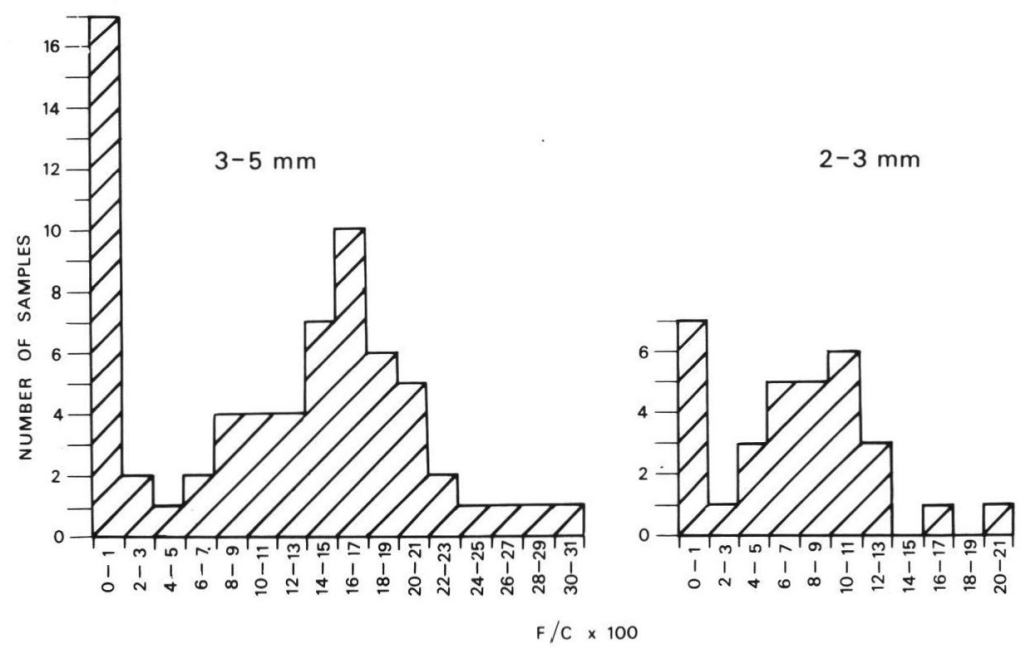

Fig. 6: Distribution of the flint-coefficient values in the fractions $3-5 \mathrm{~mm}$ and $2-3 \mathrm{~mm}$ in SE Drente. In the fraction $3-5 \mathrm{~mm}$ the results of ZANDSTRA (1976) have been included. 



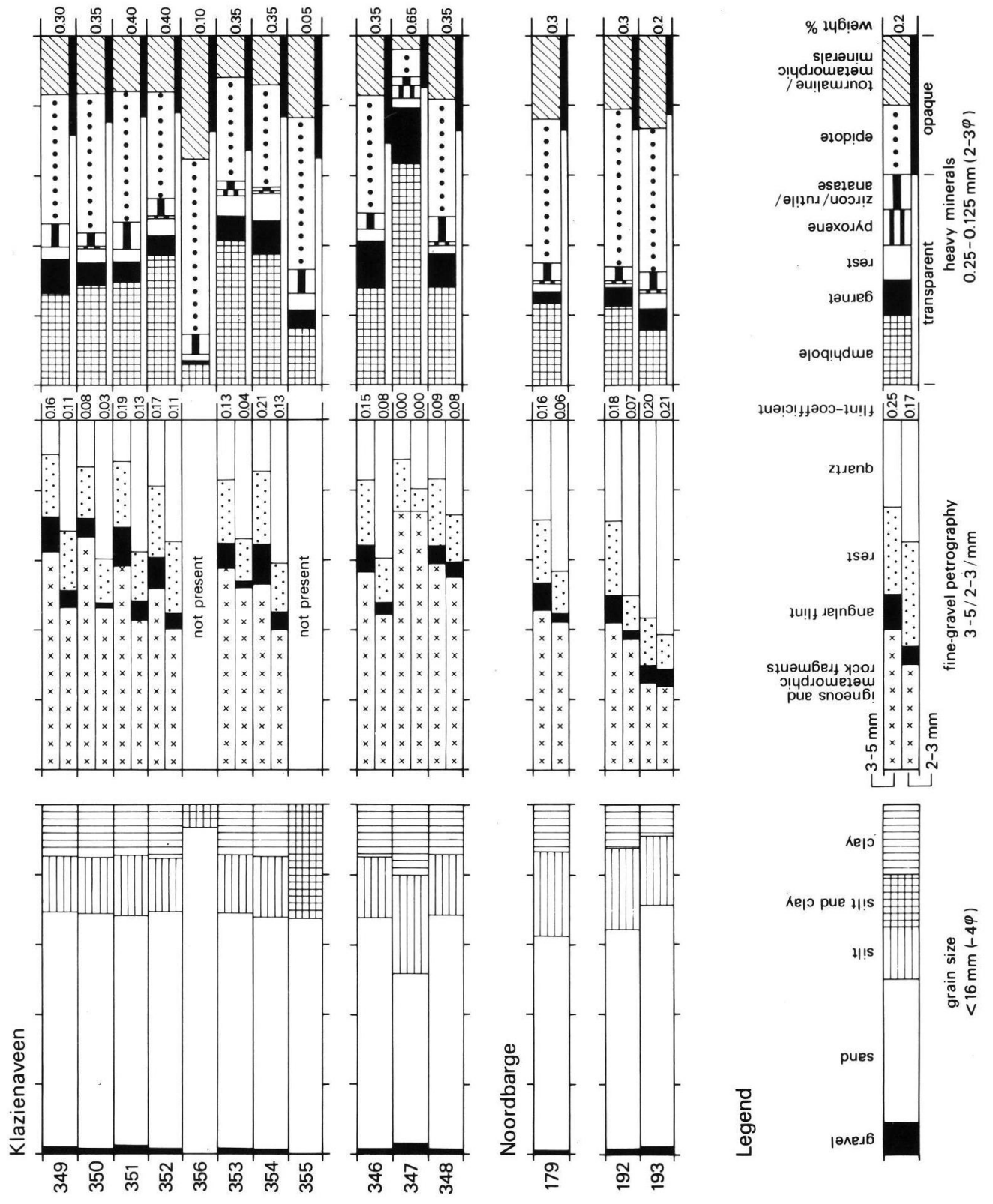

Fig. 4: Compositional characteristics of the analysed samples. For position and sediment type, see Fig. 3. For non-till samples the fraction smaller than 0.063 ( $4 \varphi$, is silt plus clay fraction) was not analysed for grain-size distribution. 
Mention must be made of the presence of pockets of gravelly sand or sandy gravel in the cryoturbated zone at Zuidbarge and Weiteveen-Noordersloot (Fig. 3, 4: samples 328 and 340), which in fine-gravel and heavy-mineral composition are akin to the flint-poor till. These gravelly pockets were also observed at Klazienaveen, but here flint-poor till was only sampled near the base of the profile, as mentioned before. Sedimentation of this material pre-dates the cryoturbation event. The contortion due to cryoturbation is prohibiting detailed interpretation, but on account of the close relation with the flint-poor till, a sedimentation during final ice retreat is assumed, through deposition of englacial debris by minor meltwater activity, or by reworking of the flint-poor till surface. From Erica, flint-poor glaciofluvial deposits have been described (RAPPOL 1983: 117-122), which occur in a dislocated position due to subglacial shearing. At Erica these sorted sediments are of a considerable volume, while those mentioned above are small pockets of several decimetres in diameter only. The gravel beds and pavements that post-date the cryoturbation event generally contain reworked flint-rich till material as well. The flint-coefficient however decreases with increasing size (sample 327 in Fig. 3, 4; for the fractions $5-8 \mathrm{~mm}$ and $>8 \mathrm{~mm}$ the F/C values are 0.04 and 0.03 respectively), indicating the stronger influence of the flint-poor till in the coarser fractions. Moreover, heavy-mineral composition and grain aspect of the sand fraction indicate that the matrix of the latter consists mainly of reworked coversand (pers. comm. Mr. H. Stoltenberg). On similar grounds, samples 329 and 330 at Zuidbarge probably contain a minor admixture of coversand material due to the cryoturbation process.

Besides the absence or near-absence of flint, the flint-poor till is characterised by a high percentage of crystalline rock fragments and few quartz grains. The heavy-mineral composition is characterised by a low percentage opaque minerals; the transparent component is dominated by amphibole (mainly green hornblende), while scores for epidote and tourmaline/metamorphic minerals are comparatively low. The characteristics of the fine-gravel and heavy-mineral composition suggest a relatively pure erratic debris, derived mainly from igneous and metamorphic rocks.

The main part of the till body in SE Drente consists of flint-rich till. This till is generally massive. Only at Emmerschans a colour-banding and compositional layering was observed, comparable to that known from a till near Lunteren, Gelderse Vallei (RAppol 1983: Fig. 87). However, lenses of sorted preglacial material within the till are not uncommon (Fig. 7; see also Zandstra 1976, Fig. 4, Rappol 1983, Figs. 56 and 87).

The flint-rich till contains in the heavy-mineral concentrate an amphibole-epidote assemblage, and differs further from the flint-poor till by a distinct amount of tourmaline/metamorphic minerals. The opaque fraction tends to be higher and the total heavy-mineral weight percentage lower than in the flint-poor till.

Apart from the presence of sorted lenses, the till profile shown in Fig. 7 has a fairly uniform composition for all compositional measures (Fig. 4). In other profiles however, such a uniform vertical composition is not present. At Zuidbarge, Noordbarge, and to a lesser extent at Weiteveen-Noordersloot, the sand fraction and the quartz content of the finegravel fractions increase towards the base of the till. A feature that was also noted at Erica (RAPPOL 1983). Near the till base compositional characteristics of the till tend to be skewed towards those of the sub-till sediment. An increase of local components near the till base is generally assumed to be indicative for subglacial formation (e.g. Rose 1974, Dreimanis 1976).

At Erica it was observed that the flint-coefficient value became higher near the till base, while in SE Drente in general, a high correlation was found between the flint-coefficient 




Fig. 7: The till profile at Klazienaveen from which samples 349-356 derive (see Fig. 4). In the upper part: cryoturbated till with pockets of coversand. At about 1/3 from below: intra-till sand lenses derived from the sub-till Peelo sediments. Till fabric no. 23 (Fig. 10) was measured at this site, below the intra-till sorted lenses.

and quartz content of the fine gravel fraction (RAPPOL 1983, Fig. 104). The profile at Zuidbarge examplifies here this type of till profile.

Finally, we may compare the grain-size distributions of both till types from Fig. 8. Both tills are characterised by a prominent mode in the fraction $0.25-0.125 \mathrm{~mm}(2-3 \varphi)$, which is in fact a general characteristic of Saalian till in the Netherland. This modal fraction seems therefore in the first place inherited from the grain-size distribution of the erratic debris. In the flint-rich till, the mode is reinforced by addition of local material, which in SE Drente consists mainly of well-sorted fine to very fine sands of the Elsterian Peelo Formation (RAPpol 1983, Fig. 98). This also explains the high standard deviation in the fine sand fractions for the flint-rich till. The flint-poor till shows a comparatively high standard deviation throughout, because samples from Erica deviate considerably by a higher clay and lower gravel and coarse sand fraction.

The contact till/sub-till sediment is generally sharply defined, although gradual transitions have been observed. At Klazienaveen the sub-till sediments were exposed over a length of some tens of metres. These sediments consisted of fine sand and occasional loamy layers, the original sedimentary structures of which were strongly contorted by deformational processes. Throughout the exposed length, the preglacial sediments at the base of the till showed recumbent fold structures. (Fig. 9), in a style similar to that described from Emmerschans and Erica (RAPPOL 1983), and interpreted to be characteristic for subglacial shear deformation. 


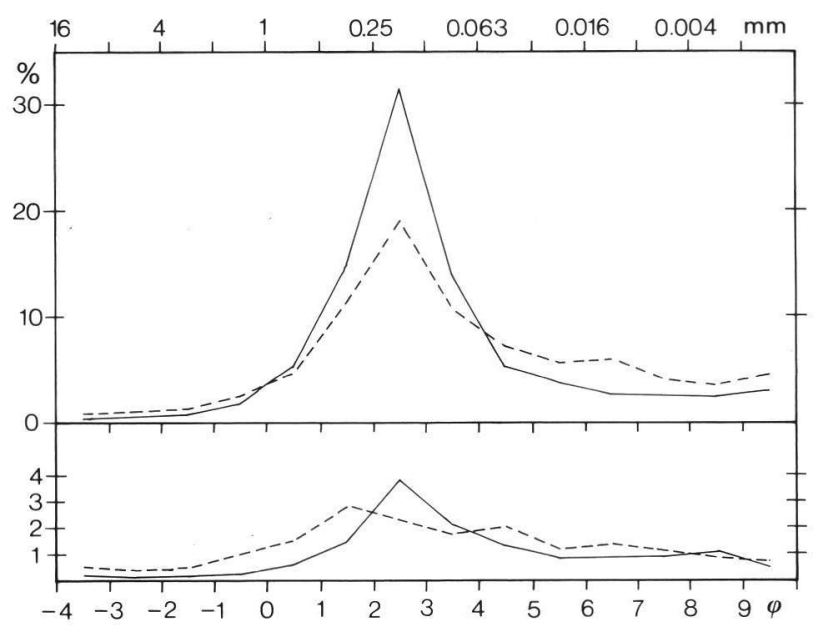

Fig. 8: Mean grain-size distribution (A) and its standard deviation (B) for flint-poor till (broken lines, 11 samples) and flint-rich till (continuous lines, 39 samples) in SE Drente.

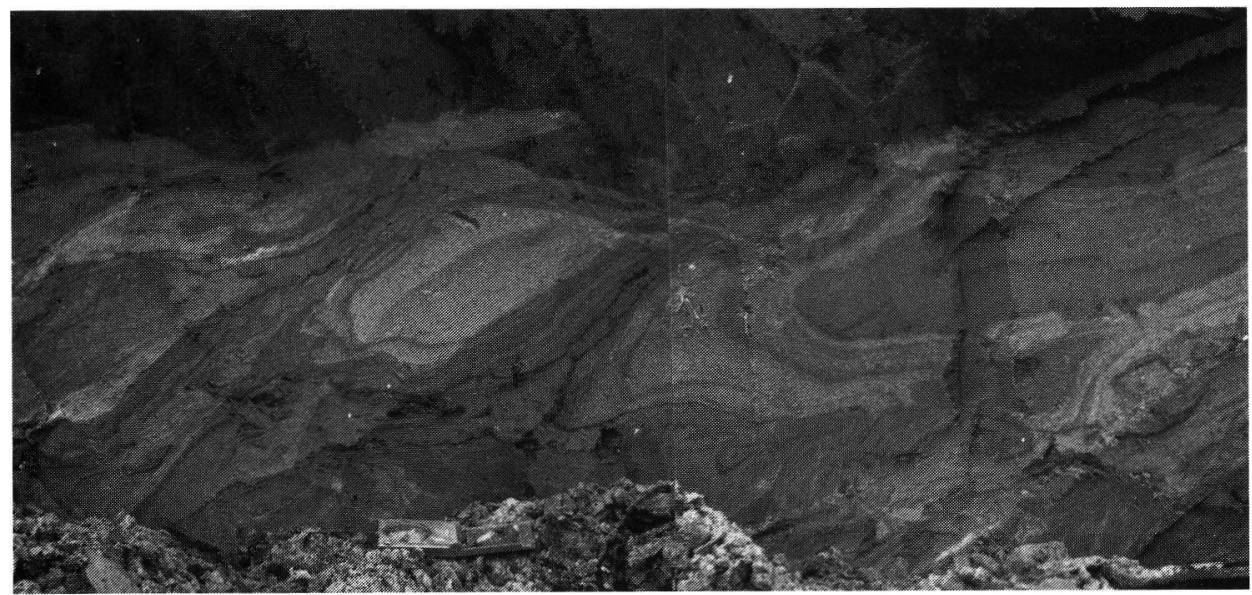

Fig. 9: Recumbent folds in sediments of loamy and sandy texture of the Peelo Formation, formed as a result of subglacial shear deformation at Klazienaveen. Compass for scale. Note interfingering of till and sand in the centre of the photograph (shear-wedging).

\section{Directional features related to ice movement}

Earlier studies in clast fabric of till in The Netherlands (DE WAARD 1949, BoEKsCHOTEN \& VeENSTRA 1967) suggested that no relation between direction of ice movement and clast orientation is present. Recent investigations however indicate that the method may yield positive results in many cases, provided that the sample is taken below the cryoturbated zone (RAPPol 1983). The results from SE Drente are given in Fig. 10. The fabric diagrams suggest a direction of ice movement from between NNE and NNW. Fig. 10 includes some 


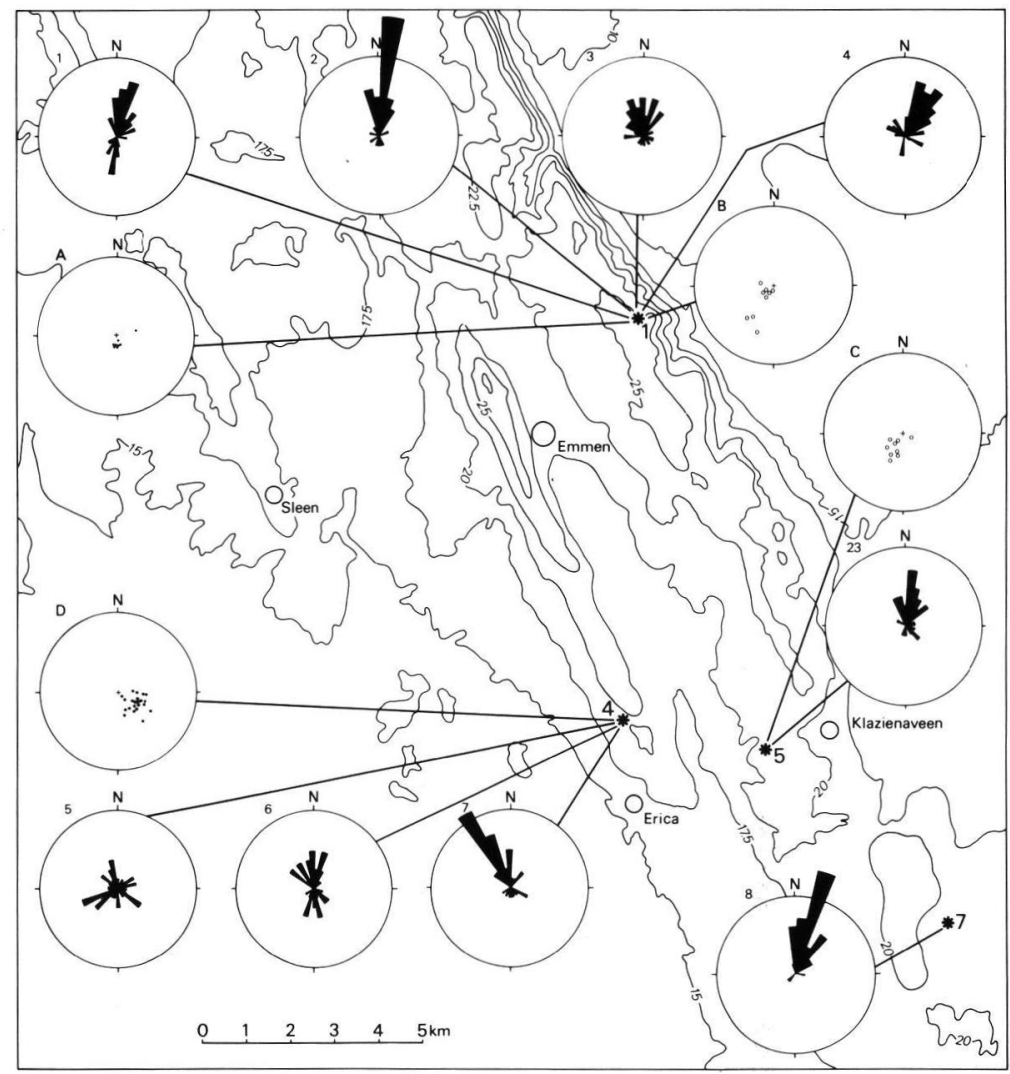

Fig. 10: Elongated clast fabric diagrams with the sence of dip recorded, and stereograms for poles to structural planes in subglacially deformed strata. All clast-fabric samples are from flint-rich till, except nos. 1 and 2 which are from the flint-poor upper till at Emmerschans. Pole to plane stereograms for: A. intra-till sand lenses, B and C, deformed Peelo sediments, and D. for the deformed complex of till and glaciofluvial sediments at Erica.

stereograms of structural planes of sedimentary layers in or directly below the till, which have been affected by subglacial shear deformation. Sub-till deformation structures at Emmerschans and Klazienaveen (diagrams B and C) suggest ice movement towards SW to SSW. Imbricated intra-till sand lenses at Emmerschans (diagram A) suggest ice movement towards S, while deformation in the upper part of the till profile at Erica (diagram D) suggests ice movement towards SE. The general impression is that local ice movement fluctuated around a N-S direction. Given the morphological development of the ridges, it is suggested that the last active ice movement can be taken as roughly parallel to the morphological lineation of the Hondsrug complex. In this respect it should be mentioned that most fabric analyses were sampled near the till base and thus may not record the last ice movement. In this context the find of Schuddebeurs (1982: 95-96) is very interesting. At a distance of $1 \mathrm{~km}$ from eachother, Schuddebeurs found two matching parts of a gabbroid boulder. The line of transport was N15W to S15E, i.e. parallel to the strike of the Hondsrug complex.

The present results are not in accordance with the model proposed by LIGTERINK (1954). According to Ligterink, an ice movement towards SSW, being related to the glaciotectonic 
thrusting in the subsoil at Emmerschans, was followed by an ice movement towards W to WSW (Ligterink 1954: Figs. 2 and 3). The latter direction he deduced from a qualitative assessment of clast orientation in a field near Emmen and from a find of two matching boulders at some distance from eachother. Concerning these findings, it can only be said that the present investigations did not yield comparative results; no indications were found for an ice movement in a western direction during any phase in the building up of the till bed.

\section{Discussion and conclusions}

Indicator-pebble counts following the method of HESEMANN indicate the prevalence of East-Baltic crystalline material throughout the till profile, and thereby do not distinguish between the two till types of the Hondsrug complex (Zandstra 1976, SCHuddebEurs 1982). Other components however demonstrate that the erratic sources in Fennoscandia must have been partly different for both tills. ZANDSTRA (1976) determined that the lower till at Emmerschans contains $33.7 \%$ flint in the fraction $1-20 \mathrm{~cm}$, against $1.1 \%$ in the upper till. These results correspond with the differences found in the value of the flint-coefficient for the fractions $3-5 \mathrm{~mm}$ and $2-3 \mathrm{~mm}$. While flint can be considered a typical South-Baltic component, mainly derived from the Cretaceous strata of South Sweden, Denmark and adjoining regions of the Baltic Sea, it follows that the Hesemann figures of crystalline, indicator-pebble assemblages cannot be translated directly into dominant source area. The more so, because till dominated by East-Baltic indicator pebbles contains a higher percentage of coarse material and moreover a higher percentage of indicator-pebbles in this coarse fraction (according to data given in Boekschoten \& VeEnstra 1967, and Schuddebeurs 1980/81). In this respect the different results obtained by LütTIG \& MAARLEVELD (1961) are significant (see section 3.1).

Be this as it may, still it is clear that the till of the Hondsrug complex differs in many aspects from that of the surrounding till areas.

An explanation of the observed compositional variability in vertical sections has been explained in different ways (e.g. DE WAARD 1949, VeENSTRA 1963, ZandSTRA 1976, Rappol 1983). First it should be noted that the presence of a flint-poor till on top of a flint-rich till is not peculiar to the Hondsrug complex. Similar two-till sections are known from the central Netherlands, where till contains a Central-Baltic indicator-pebble assemblage (ZANDSTRA 1983), and from the southern border zone of the Drente till plateau, where a flint-poor East-Baltic till is found on top or in the upper part of flint-rich West-Baltic till (DE WAARD 1949). Also from northern Germany similar petrographic sequences have been described (e.g. EhLERs 1983). The association of the phenomenon with tills of a very different indicator-pebble composition, and the presence of only one till bed throughout The Netherlands suggest that an explanation postulating different directions of ice movement and/or temporary deglaciation is unnecessarily complicated. Indications for these assumptions have never been found. On the contrary, till profile characteristics suggest continuous ice cover during formation of both tills, and more or less constant directions of ice flow. Following these considerations, a mechanism has been proposed that envisages the presence of a petrographic stratification within the ice, and which relates to the distribution of rock types in the up-glacier area (RAPPOL 1983). Among the typical Fennoscandian components, flint is derived from the area located closest to the depositional area, and therefore is expected to be abundant especially in the lower part of the debris-rich basal ice zone. Such a petrographic stratification could be maintained during the transportational and depositional phase, and result in a petrographic stratification as found in the Hondsrug till. The flintpoor till thus represents material transported on a relatively high level within the glacier, 
where it could not be mixed with material eroded in the southern Baltic. The mechanism for upward dispersion of debris in basal ice layers is sought in the style of deformation at the base of ice sheets and glaciers in general, where recumbent folding and shearing allow for vertical transport of debris. Observations in modern glaciers provide ample evidence for the operation of this process (e.g. Boulton 1970; SHumski 1964; Huddleston 1976; SHaw 1977).

On the other hand, these same deformational processes may disturb such a petrographic stratification during deposition. The lense of flint-poor till near the base of the flint-rich till at Klazienaveen can only be explained as a result of deformation processes which brought lower till material on top of upper till material by differential shear.

Erosion by the ice is not limited to its source areas, but considerable erosion may take place in the depositional areas. On account of the model explained above, it can be expected that local material will be present especially in the lower part of the till profile. In SE drente this is evident through the higher quartz percentage and sandiness often found in samples taken from the lower part of the till. Again, differential shear may disturb such an ideal stratification, as examplified by the presence of lenses of sorted material within the till, but generally these are only found in the lower $1.5 \mathrm{~m}$.

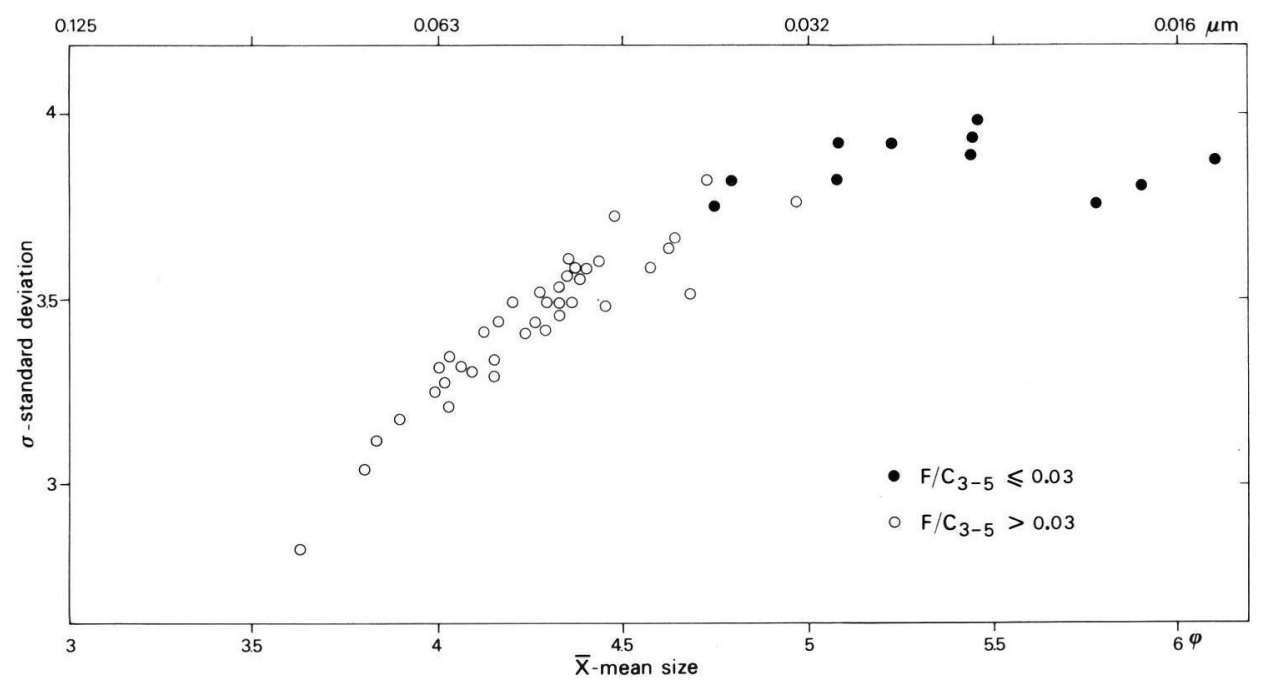

Fig. 11: Mean size plotted against standard deviation (moment measures after FrIEDMAN 1967) for till samples from SE Drente. The moment measures were calculated for the fraction smaller than $2 \mathrm{~mm}$ $(-1 \varphi)$ for grain-size classes at 1 interval.

Fig. 11 shows the strong relation that exists between mean. size and sorting. Samples containing excess sand are better sorted (lower, left-hand part of the diagram) as a result of incorporation of well-sorted local sands. In this figure, quartz content of the fine-gravel fraction can be taken roughly to increase from upper right to lower left. Likewise, Fig. 12 shows the intermediate position of the flint-rich till between the flint-poor till and the local sediments with respect to heavy-mineral composition. However, it should be noted that the difference in heavy-mineral composition will be partly caused by differences in the erratic component, as with the incorporation of flint in the southern Baltic, also the heavy-mineral composition may have changed. 
Field evidence suggests that local material is predominantly incorporated by means of deformational processes at the contact of debris-rich basal ice and underlying local sediments (RAPPOL 1983).

\section{The origin of the Hondsrug complex}

Several authors have suggested that on account of the available bore-hole and seismic data, a tectonic origin for the Hondsrug complex seems out of the question (DE JoNG 1967: 350-51, Ruegg \& Zandstra 1977: 66, TER WeE 1979: 127). These data appear to be mainly unpublished, for which reason the present author cannot judge the 'impossibility of the tectonic origin'. However, on different grounds a glacial origin can be readily accepted as will be discussed below.

First, the detailed information available on the distribution of crystalline Fennoscandian indicator-pebble assemblages indicates that till of the Hondsrug complex is consistently characterised by the prevalence of pebbles of East-Baltic provenance (ScHudDEBEURS \& Zandstra 1983: Fig. 354). Outside the Hondsrug complex, the tills contain mainly WestBaltic assemblages, where East-Baltic assemblages are only found occasionally in association with so-called red till floes (DE WAARD 1949). It seems too much of a coincidence if the area characterised by a completely different till, happens to be also the area that was affected by tectonic movements.

A second consideration concerns the linear morphology of the Hondsrug complex. In other areas such a morphological lineation is generally assumed to reflect the direction of ice movement. The ridges are generally built of till, and in some parts of northern Germany a good correlation was found between the orientation of the ridges and the preferred orientation of elongated clasts in the till (e.g. Richter 1950, SchröDER 1978, EHLERs \& STEPHAN 1983). Also in North America, similar features (macroflutes) were found to parallel the tillforming direction of ice movement (Gravenor \& Meneley 1958, Shaw 1977, Jones 1982). Within these flutes, variations in clast-fabric orientation occur which indicate transverse components of ice movement in the direction of the ridge axes (SHAw 1977, JonES 1982).

The present results of the clast-fabric analyses and the additional directional data strongly suggest that the general direction of ice movement during formation of the Hondsrug morphology was parallel to the elongation of the ridges, i.e. towards SSE. The action of secondary transverse components of flow in the basal ice could explain that there is not a perfect parallellism between ridge orientation and clast fabric, provided that the fabrics really record the last active ice movement. Flow convergence from a northern direction may be indicated by fabrics and deformations structures at e.g. Emmerschans, while measurements at Erica suggest convergence from a western direction.

In this context it may be interesting to note that, if the ridges of the Hondsrug complex are comparable to the macroflutes described from Canada, that then the preservation of the two tills on top of eachother seems not consistent with the model of secondary flow cells as proposed by SHAw (1977). In this model we expect a thorough mixing of the erratic components.

If one accepts a glacial origin of the Hondsrug complex as proposed here, then several questions arise: 1 . concerning its phasing in time with respect to the SW moving ice of the surrounding till areas, 2 . whether it concerns an isolated phenomenon or that similar events have taken place elsewhere, and 3. concerning the mechanism behind the Hondsrug event. 


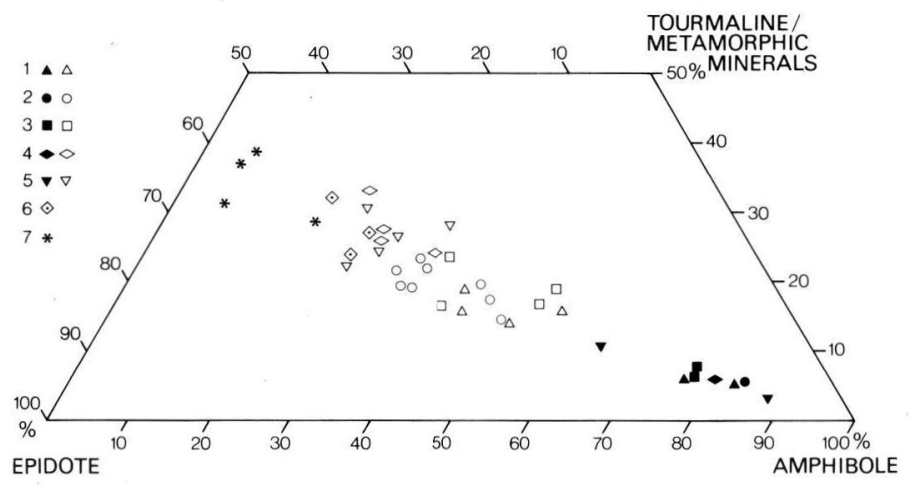

Fig. 12: Triangular diagram showing the relative frequencies of amphibole, epidote and tourmaline/metamorphic minerals in the fraction $0.25-0.125 \mathrm{~mm}(2-3 \varphi)$, for till samples from: 1 . Weiteveen-Noordersloot, 2. Klazienaveen, 3. Erica, 4. Emmerschans, 5. Zuidbarge, 6. Noordbarge, and 7. sediments of the Peelo Formation from various locations. Flint-poor till samples in black, flintrich samples as open symbols.

As mentioned before, on both sides of the Hondsrug complex, a morphological lineation is present which is oriented in a NE-SW direction (Fig. 2), suggesting ice movement towards SW. This latter lineation is transected by that of the Hondsrug complex, in such a way that the lineation of the till plateau W of the Hondsrug complex comes, so to speak, to a dead end. The Hondsrug direction is thus superposed on the NE-SW lineation and must be younger. Similar phenomena, in which a younger ice movement cuts across an older one and eradicates the older morphological lineation are well known from Canada (JoNEs 1982: 51-53, Prest 1983: 56).

Also the compositional characteristics of the erratic debris in the tills of the Hondsrug complex may suggest that it was formed during a relatively late phase of the glacial cover. In this respect two factors may have played a role, and probably worked in the same direction. First, during a glaciation the ice divide in the Fennoscandian source area is generally assumed to have shifted in an eastern direction. The presence of East-Baltic till on top of West-Baltic till was related to this shifting ice divide and associated differences in source material and direction of ice movement (MOLENGRAaFF $\&$ VAN WATERSCHOOT VAN DER GRACHT 1913, Veenstra 1963: 12). Recently, Ehlers $(1981,1983)$ found much evidence for the application of such a model in northern West Germany. In Ehlers's model, the direction of ice movement shifted gradually from towards $S$ to towards $\mathrm{W}$ in the depositional areas during each glaciation. The older ice movements carried predominantly West-baltic material, the younger ice movement East-Baltic material. With respect to the Hondsrug complex, it can be noted that the younger ice movement indeed deposited East-Baltic till, but that the succession in the direction of ice movements is opposite to that predicted by Ehlers model, i.e. an older ice movement towards SW and a younger ice movement towards SSE. This poses a real problem which cannot be solved easily. A second factor of importance may be the consequence of the model of the petrographic stratification of englacial debris within the ice prior to deposition, as it was discussed shortly in the preceding section (see RAPPOL 1983 for further discussion). This model predicts that far-travelled material is deposited on top of material eroded nearer to the depositional area. If explains the presence of East-Baltic till on top of West-Baltic till and flint-poor till on top of flint-rich till. Because the Hondsrug complex presently forms one of the highest parts of the Drente till plateau, we can only imagine its formation when the younger ice movement was channelled by large bodies of 
stagnant ice (see also Jones 1982: 53), the more so because only one till bed is present throughout the Drente plateau and because ice-marginal formations related to the Hondsrug event seem absent. If after a period of stagnation and degradation part of the ice had been reactivitated for whatever reason, it could deliver a different till type, consisting of relatively more far-travelled material, because part of the debris transported at the lowest level had been deposited.

It is not intended to suggest that a clear-cut solution can be given. The matter is clearly very complicated, and the mechanism behind the event not obvious. Part of the solution may be present in the sediments of the North Sea basin, of which very little is known yet. Moreover, it is possible that initiations of the observed features must be sought fare more up-glacier, in the Fennoscandian source areas, where however most evidence for Saalian events has been removed during the Weichselian. The prospects for finding the solution seem therefore not so good at present.

Finally, some words on the extent of the Hondsrug event, and on possible analogous phenomena. The East-Baltic till occurrences in eastern Groningen as indicated on the map of SchudDEBeurs \& Zandstra (1983: Fig. 354) are possibly related to the Hondsrug till. Also the SE moving ice derived by SCHRÖDER (1978) on the western flank of the Hümmling ridge complex (some $40 \mathrm{~km}$ E of Emmen, in northern Germany) is probably synchronous to the formation of the Hondsrug.

Morphological lineations oriented in a NNW-SSE direction are also present in the area of the Syker Geest (RICHTER 1950; see also Fig. 2 of this paper). This might possibly indicate that an event similar to that of the Hondsrug complex did take place in the area of the lower Weser valley. According to EhLers \& STEPHAN (1983: Fig. 284) however, the ice movement towards SSE during formation of the Syker-Geest lineation is older than the ice movement towards SW recorded in Saalian till N of Bremen. Whether this was derived from decisive evidence or rather prompted as a consequence of the glaciation model as proposed by $\mathrm{EH}_{\mathrm{H}}$ LERS $(1981,1983)$ is not clear to the present author.

Moreove, there are indications that also the last ice movement in the Gelderse Vallei was more or less synchronous to the Hondsrug event. This derives mainly from the similarities in the direction of ice movement, which follows from the valley morphology and clast fabric and structural analyses at a till exposure near Lunteren (RAPPOL 1983), and from the similarities in the development of the petrographic composition of the till profile. It is intended however to discuss this matter in more detail elsewhere.

\section{Acknowledgements}

I am indebted to Prof. Dr. G.C. Maarleveld and Drs. Dick van der W Wteren for critically reading the manuscript and for the valuable suggestions that helped to improve it. Thanks are also due to: Kier van Gijssel for assistence in the field, HenK Stoltenberg for the heavy-mineral analyses, Leo Hoitinga for the grain-size analyses, OdA Bergmeijer-DE VRÉ for making the drawings and HAN VAN MAAREN for the reproductions. Fieldwork was supported by a grant from the institutional board of the Physical Geography and Soil Science Laboratory. 


\section{References}

Boekschoten, G.J. \& Veenstra, H.J. (1967): Over stenenorientatie in het nederlandse keileem. Geol. Mijnbouw, 46; 195-205, 10 Fig., 2 Tab.; Leiden.

Boissevain, H. (1950): Over de praeglaciale morfologie van Noord-Nederland. - Geol. Mijnbouw, 12: 37-40. 1 Fig.; Den Haag.

Boulton, G.S. (1970): On the origin and transport of englacial debris in Svalbard glaciers. - J. Glaciol., 9: 213-229, 7 Fig., 1 Tab.; Camebridge.

Calker, F.J.P. (1885): Diluviales aus der Gegend von Neu Amsterdam. - Z. dt. geol. Ges., 37: 792-802; Berlin.

Dreimanis, A. (1976): Tills: their origin and properties. — In: Glacial till, ed. by R.F. Legget: 11-49; Roy. Soc. Can., Spec. Publ., 12; Ottawa.

Dubors, E. (1902): De geologische samenstelling en de wijze van ontstaan van den Hondsrug in Drenthe. - Versl. K.N.A.W., 11: 43-50 and 150-152; Amsterdam.

Edelman, C.H. \& Maarleveld, G.C. (1958): Pleistozän-geologische Ergebnisse der Bodenkartierung in den Niederlanden. - Geol. Jb., 73: 639-684, 26 Abb., 3. Tab., 2 Taf.; Hannover.

EHLERs, J. (1981): Problems on the Saalian stratigraphy in the Hamburg area. - Meded. Rijks Geol. Dienst, 34: 26-29, 1 Fig.; Den Haag.

- (1983): Different till types in North Germany and their origin. - In: Tills and Related Deposits, ed. by E.B. Evenson \& Ch. Schlüchter \& J. Rabassa: 61-80, 16 Fig.; Rotterdam (Balkema).

- \& Stephan, H.-J. 1983: Till fabric and ice movement. - In: Glacial Deposits in North-West Europe, ed. by J. Ehlers: 267-274, 7 Fig.; Rotterdam (Balkema).

FABER, F.J. (1942): Nederlandsche Landschappen. - Bodem, Grond en Geologische Bouw. 400p., 152 Fig., 33 Tab.; Gorinchem (Noordduijn \& Zn.).

Friedman, G.M. (1967): Dynamic processes and statistical parameters compared for size frequency distribution of beach and river sands. - J. Sed. Petr. 37: 327-354, 19 Fig., 3 Tab.; Tulsa.

GANS, W. DE (1980): Outlines of the Late Quaternary history of the Drentsche Aa valley (Drente, The Netherlands). - Geol. Mijnbouw, 59: 353-362, 7 Fig., 1 Tab.; Den Haag.

Gravenor, C.P. \& Meneley, W.A. (1958): Glacial flutings in central and northern Alberta. - Am. J. Sci., 256: 715-728, 8 Fig.; New Haven.

Hudleston, P.J. (1976): Recumbent folding in the base of the Barnes Ice Cap, Baffin Island, Northwest Territories, Canada. - Geol. Soc. Am. Bull., 87: 1684-1692, 9 Fig.; Washington.

JoNEs, N. (1982): The formation of glacial flutings in east-central Alberta. - In: Research in Glacial, Glacio-fluvial and Glacio-lacustrine Systems, ed. by Rd. Davidson-Arnott \& W. Nickling \& B.D. Fahey: 49-70, 7 Fig., 2 Tab.; Norwich (Geo Books).

Jong, J.D. DE (1967): The Quaternary of The Netherlands. — In: The Geological Systems: The Quaternary 2, ed. by K. Rankema: 301-426, 36 Fig., 3 Tab.; New York, London, Sydney (Interscience Publ.).

JoNkER, H.G. (1905): Some observations on the geological structure and origin of the Hondsrug. Roy. Acad. Sci., Proc. Meet. June 24, 1905: 96-104; Amsterdam.

Ligterink, G.H. (1954): De Hondsrug en het dal van de Oer-Eems. - T.K.N.A.G., 71: 105-121, 12 Fig.; Leiden.

LÜTTIG, G. (1958): Methodische Fragen der Geschiebeforschung. - Geol. Jb., 75: 361-418, 17 Abb., 1 Tab., 3 Taf.; Hannover.

- \& Maarleveld, G.C. (1961): Nordische Geschiebe in Ablagerungen prä - Holstein in den Niederlanden (Komplex von Hattem).-Geol. Mijnbouw, 40: 163-174, 6 Abb.; Den Haag. 
MaArleveld, G.C. (1956): Grindhoudende midden-pleistocene sedimenten. Het onderzoek van deze afzettingen in Nederland en aangrenzende gebieden. - Meded. Geol. Stichting, Ser. C-VI, 6: 105 p., 48 Fig., 26 Tab.; Maastricht.

- Cate, J.A.M. ten \& LANGe, G.W. DE (1977): Geomorfologische kaart van Nederland, schaal 1:50.000. Legenda. 20 pp. Wageningen/Haarlem (Stiboka/Rijks Geol. Dienst).

Martin, J. (1894): Diluvialstudien II: Das Haupteis ein baltischer Strom. - Jber. Naturw. Ver. Osnabrück X: 1-70, 2 Taf.; Osnabrück.

Molengraaff, G.A.F. \& Waterschoot van der Gracht, W.A.J.M. van (1913): Niederlande. Handbuch der Regionalen Geologie, herausgeg. von G. Steinmann \& O. Wilckens, 1. Bd., 3. Abt.: 98 p., 20 Fig., 14 Tab.; Heidelberg.

Prest, V.K. (1983): Canada's Heritage of Glacial Features. - Geol. Surv. Can., Misc. Rep., 28: 119 p., 90 Fig.; Ottawa.

Rappol, M. (1983): Glacigenic Properties of Till. Studies in glacial sedimentology from the Allgäu Alps and The Netherlands. - Publ. Fys.-Geogr. Bodemk. Lab., Univ. Amsterdam, 34: 225 p., 108 Fig., 3 App.; Amsterdam.

- \& Stoltenberg, H.M.P. (1984): Compositional variability of Saalian till in The Netherlands and its origin. (Boreas, Oslo. - [In press]

RichteR, K. (1950): Die Entwicklungsgeschichte der Täler zwischen Lathen und Verden/Aller. Geol. Jb., 65: 641-645, 5 Abb.; Hannover.

RoELEveld, W. (1970/71): The morphology of the Pleistocene surface in the marine-clay district of Groningen (The Netherlands). - Ber. Rijksd. Oudh. Bodemond., 20/21: 7-25, 9 Fig., 2 Tab.;

Rose, J. (1974): Small-scale spatial variability of some sedimentary properties of lodgement till and slumped till. - Proc. Geol. Ass., 85: 223-237, 9 Fig., 4 Tab.; London.

Ruegg, G.H.J. \& Zandstra, J.G. (1977): Pliozäne und Pleistozäne gestauchte Ablagerungen bei Emmerschans (Drenthe, Niederlande). - Meded. Rijks Geol. Dienst, 28: 65-99, 13 Abb., 4 Tab., 7 Taf.; Den Haag.

SCHRöDER, E. (1978): Geomorphologische Untersuchungen im Hümmling. - Gött. Geogr. Abh., 70: 113 p., 18 Abb., 7 Beil.; Göttingen.

Schuddebeurs, A.P. (1980/81): Die Geschiebe im Pleistozän der Niederlande. - Der GeschiebeSammler, 13; 163-178 und 14: 33-40, 91-103, 147-158, 32 Abb., 6 Tab.; Hamburg.

- (1982): Zwerfsteentellingen in Noord-Nederland.-Meded. Werkgr. Tert. Kwart. Geol. 19: 81-108, 5 Fig., 8 Tab.; Leiden.

- \& Zandstra, J.G. (1983): Indicator pebble counts in the Netherlands. - In: Glacial Deposits in North-West Europe, ed. by J. Ehlers: 357-360, 2 Fig., 1 Tab.; Rotterdam (Balkema).

Shumskil, P.A. (1964): Principles of Structural Glaciology. - 497 p., 124 Fig., 7 Tab.; New York (Dover).

SHAw, J. (1977): Till body morphology and structure related to glacier flow. - Boreas, 6: 189-201, 13 Fig.; Oslo.

Veen, J. van (1925): Heuvelruggen in Drenthe. - Nw. Drent. Volksalm., 43: 71-80, 3 Fig.; Assen.

VeEnstra, H.J. (1963): Microscopic Studies of Boulder Clay. - Diss. Univ. Groningen: 211 p., 29 Fig., 8 Tab., 13 Pl., 4 App.; Groningen.

WAARD, D. DE (1949): Glacigeen Pleistoceen. Een geologisch detailonderzoek in Urkerland (Noordoostpolder). - Verh. Ned. Geol. Mijnb. Gen., XV: 70-246, 125 Fig., 3 Beil.; Den Haag.

WEE, M.W. TER (1979): Toelichtingen bij de geologische kaart van Nederland 1:50.000. Blad Emmen West (17 W) en Blad Emmen Oost (17 0). 218 p., 62 Fig., 18 Beil.; Haarlem (Rijks Geologische Dienst).

- (1983): The Saalian Glaciation in the northern Netherlands. - In: Glacial Deposits in NorthWest Europe, ed. by J. Ehlers: 405-412, 8 Fig., 1 Tab.; 4 Pl.; Rotterdam (Balkema). 
ZAGwIJN, W.H. (1973): Pollenanalytic studies of Holsteinian and Saalian beds in the northern Netherlands. - Meded. Rijks Geol. Dienst, N.S., 24: 139-156, 13 Fig., 2 Tab., 8 encl.; Haarlem.

ZANDSTRA, J.G. (1976): Sedimentpetrographische Untersuchungen des Geschiebelehms von Emmerschans (Drenthe, Niederlande) mit Bemerkungen über eine Typeneinteilung der SaaleGrundmoräne. - Eiszeitalter u. Gegenwart, 37: 30-52, 7 Abb., 6 Tab.; Öhringen.

- (1983): Fine gravel, heavy mineral and grain-size analyses of Pleistocene, mainly glacigenic deposits in the Netherlands. - In: Glacial Deposits in North-West Europe, ed. by. J. Ehlers: 361-376, 15 Fig., 2 Tab., 4 Pl.; Rotterdam (Balkema).

Manuskript accepted on 10.4.84. 
